\title{
The Effect of Chilli Extract on Gastroprotective Function in Male
}

\author{
Tahyatul Bariroh ${ }^{1 *}$, Siska Siska ${ }^{2}$ \\ ${ }^{1}$ Departement of Biology Pharmacy, Universitas Muhammadiyah Prof. Dr HAMKA, Jakarta, Indonesia \\ ${ }^{2}$ Departement of Pharmacology, Faculty of Pharmacy and Sciences, Universitas Muhammadiyah Prof. Dr HAMKA, Jl. \\ Delima II/IV Klender, Jakarta 13460, Indonesia
}

Submitted 17 April 2020; Revised 29 August 2020; Accepted 24 September 2020; Published 05 February 2021

*Corresponding author: tahyatul_bariroh@uhamka.ac.id

\begin{abstract}
Chilli is one of plant from genus Capsicum and as vegetable commodities most consumed by the Indonesian people. Chilli contains a unique compound called capsaicin which gives a burning sensation like burning when consumed. This research aims to determine the effect of chilli extract on gastroprotection in the stomach of mice. The study used 35 white male rats were divided into seven groups, one group as the control group, and six groups were given extracts from three varieties of chilli (red chilli, green chilli, and chilli) with high doses $(1 \mathrm{~g} / \mathrm{kg}$ bb) and low doses $(0.5 \mathrm{~g} / \mathrm{kg} \mathrm{bb})$ for 14 days. On the $15^{\text {th }}$ day, gastric decapitation and isolation were carried out to make histological preparations of the rat's stomach. The results showed mucosal tissue in the stomach of rats given a dose of $0.5 \mathrm{~g} / \mathrm{kg} \mathrm{BW}$ remained in normal condition compared to the group of rats given high doses of chilli. In this group, a lot of damage to the gastric mucosal tissue of rats (ulcers). This study concludes that consuming $0.5 \mathrm{~g} / \mathrm{kg}$ BW chilli does not cause damage to the gastric mucosal tissue of rats.
\end{abstract}

Keywords: Chilli, Gastric mucose, Gastroprotective

\section{Pengaruh Ekstrak Cabai Terhadap Gastroproteksi Pada Tikus Putih Jantan}

\begin{abstract}
Abstrak
Cabai merupakan tanaman dari genus Capsicum yang menjadi salah satu komoditas sayuran yang banyak dikonsumsi oleh masyarakat Indonesia. Cabai mengandung suatu senyawa khas yang disebut capsaicin yang memberikan sensasi panas seperti terbakar apabila dikonsumsi. Penelitan ini bertujuan untuk mengetahui pengaruh ekstrak cabai terhadap gastroproteksi pada lambung tikus. Penelitian menggunakan 35 ekor tikus putih jantan dengan berat badan sekitar 200 gram yang dibagi menjadi 7 kelompok, yaitu kelompok kontrol, dan enam kelompok diberikan ekstrak dari tiga varietas cabai yaitu cabai merah, cabai hijau, dan cabai rawit dengan dosis tinggi $(1 \mathrm{~g} / \mathrm{kg} \mathrm{bb})$ dan dosis rendah $(0,5$ $\mathrm{g} / \mathrm{kg}$ bb) selama 14 hari. Pada hari ke 15 dilakukan dekapitasi dan isolasi lambung tikus untuk dibuat preparat histologi lambung tikus. Hasil penelitian menunjukkan jaringan mukosa dan submukosa pada lambung tikus yang diberikan dosis $0,5 \mathrm{~g} / \mathrm{kg}$ BB tetap dalam kondisi normal dibandingkan dengan kelompok tikus yang diberikan cabai dosis tinggi. Pada kelompok tersebut banyak terjadi kerusakan pada jaringan mukosa dan submukosa lambung tikus (ulkus). Hasil penelitian ini dapat disimpukan bahwa mengkonsumsi cabai dosis $0,5 \mathrm{~g} / \mathrm{kg}$ BB tidak menyebabkan kerusakan pada jaringan mukosa dan submukosa lambung tikus.
\end{abstract}

Kata Kunci: Cabai, Gastroproteksi, Mukosa Lambung 


\section{Pendahuluan}

Lambung merupakan organ berbentuk kantung yang terletak di antara esofagus dan usus halus. Lambung memiliki beberapa fungsi penting terkait sistem pencernaan yaitu untuk menyimpan makanan, mensekresikan asam hidroklorida $(\mathrm{HCl})$ dan enzim-enzim pemecah protein, dan mencampur makanan dengan sekresi lambung sebelum diteruskan ke duodenum. ${ }^{1}$ Pada lambung normal, terdapat dua mekanisme yang bekerja dan mempengaruhi kondisi lambung, yaitu faktor pertahanan (defense) lambung dan faktor perusak (aggressive) lambung. Kedua faktor ini, pada lambung sehat bekerja seimbang, sehingga lambung tidakmengalamikerusakan/ luka. Faktor perusak lambung meliputi: (1) faktor perusak endogen/berasal dari dalam lambung sendiri antara lain $\mathrm{HCl}$, pepsin, dan garam empedu, (2) faktor perusak eksogen, misalnya obat-obatan, kafein, alkohol, dan bakteri. Faktor pertahanan lambung tersedia untuk melawan atau mengimbangi kerja dari faktor perusak lambung. ${ }^{2}$ Faktor/ sistem pertahanan pada lambung meliputi lapisan mukosa lambung itu sendiri. Pada keadaan normal, tidak terjadi kerusakan karena adanya sawar mukosa yang dibentuk oleh mukus dan $\mathrm{HCO}_{3}{ }^{-}$. Ketidakseimbangan antara faktor perusak dan faktor pertahanan dapat mengakibatkan kerusakan pada selsel lambung, yang pada akhirnya akan membentuk ulkus (luka) lambung/peptikum.

Makanan yang dianggap berperan dalam kerusakan jaringan pada lambung salah satunya adalah mengkonsumsi cabai. Cabai merupakan tanaman genus Capsicum yang berperan sebagai bumbu yang paling banyak digunakan di dunia. Cabai merupakan komoditas hortikultura penting di Indonesia yang dikonsumsi oleh sebagian besar penduduk tanpa memperhatikan tingkat sosial. Masyarakat Indonesia dapat dikatakan penggemar cabai terbesar di dunia. Menurut data Badan Pusat Statistik (BPS), ratarata konsumsi cabai per kapita adalah 3,05 $\mathrm{kg} / \mathrm{kapita}$. Indonesia membutuhkan cabai sebesar 118.800 ton per tahun dengan jumlah penduduk sebanyak 237.6 juta (sensus tahun 2010). ${ }^{3}$
Cabai mengandung suatu senyawa khas yang disebut capsaicin yang memberikan sensasi panas seperti terbakar apabila dikonsumsi. Tingkat kepedasan cabai berbeda-beda tergantung pada kadar capsaicin nya. Capsaicin terdapat di bagian plasenta buah cabai yang dekat biji. ${ }^{4}$ Namun, penelitian terbaru menyebutkan bahwa cabai yang dikonsumsi dengan dosis yang tepat dapat membantu mekanisme proteksi lambung. ${ }^{5-6}$ Penelitian ini bertujuan untuk mengetahui pengaruh ekstrak tiga varietas cabai yang sering dikonsumsi masyarakat Indonesia dengan dosis tertentu terhadap aktivitas gastroproteksi.

\section{Metode}

2.1. Alat

Alat yang digunakan pada penelitian ini di antaranya kandang hewan coba, sonde tube, mikroskop olympus, alat-alat bedah tikus.

\subsection{Bahan}

Bahan yang digunakan dalam penelitian ini diantaranya ekstrak etanol $70 \%$ tiga varietas cabai (cabai merah (Capsicum annuum L), cabai hijau (Capsicum annuum L), cabai rawit (Capsicum frutescens $\mathrm{L}$ ), formaldehid, $\mathrm{NaCl} 0,9 \%, \mathrm{NaCMC}$, lambung tikus, larutan pembuatan preparat hematoxylin eosin (HE).

\subsection{Prosedur Rinci}

Tiga varietas cabai yang digunakan dalam penelitian ini diperoleh dari pasar lokal dan dideterminasi di Pusat Penelitian Biologi Herbarium Bogoriense Bidang Botani Lembaga Ilmu Pengetahuan Indonesia (LIPI) Bogor. Cabai yang digunakan terlampir pada Gambar 1. Buah cabai yang digunakan dalam penelitian ini dibuat simplisia serbuk dengan cara dikeringkan menggunakan oven simplisia di Laboratorium Farmakognosi FFS Uhamka dengan suhu $50^{\circ} \mathrm{C}$ selama 160 menit. Cabai yang sudah dikeringkan dibuat serbuk dengan cara diblender dan diayak menggunakan ayakan mesh nomor 40. Serbuk simplisia diekstraksi secara maserasi menggunakan pelarut alkohol $70 \%$ dan dievaporasi hingga menjadi ekstrak kental. Ekstrak dilakukan 


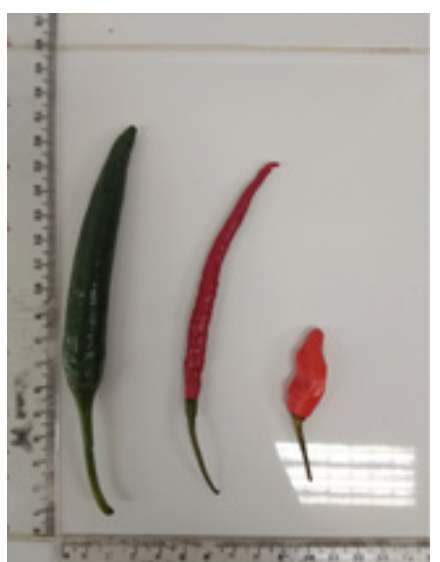

Gambar 1. Cabai hijau (Capsicum annuum L), cabai merah (Capsicum annuum L), cabai rawit (Capsicum frutescens $L$ )

skrining fitokimia. Pengujian gastroproteksi pada tikus dilakukan dengan memberikan ekstrak cabai secara oral (sonde) pada tikus putih jantan dengan dosis $0,5 \mathrm{~g} / \mathrm{kg}$ bb dan $1 \mathrm{~g} / \mathrm{kg}$ bb per hari selama 14 hari. Tikus dibagi menjadi 7 kelompok dengan masingmasing kelompok terdiri atas 5 ekor tikus. Kelompok tersebut yaitu: kelompok kontrol (tanpa diberikan ekstrak), kelompok A diberikan ekstrak cabai rawit dosis $0,5 \mathrm{~g} / \mathrm{kg}$ bb, kelompok B diberikan ekstrak cabai rawit dosis $1 \mathrm{~g} / \mathrm{kg}$ bb, kelompok $\mathrm{C}$ diberikan ekstrak cabai merah dosis $0,5 \mathrm{~g} / \mathrm{kg} \mathrm{bb}$, kelompok D diberikan ekstrak cabai merah dosis $1 \mathrm{~g} /$ $\mathrm{kg}$ bb, kelompok E diberikan ekstrak cabai hijau dosis $0,5 \mathrm{~g} / \mathrm{kg}$ bb, kelompok $\mathrm{F}$ diberikan ekstrak cabai hijau dosis $1 \mathrm{~g} / \mathrm{kg}$ bb. Pada hari ke 15 dilakukan dekapitasi dan isolasi lambung tikus untuk dibuat preparat histologi lambung. Histologi lambungnya diamati menggunakan mikroskop.

\section{Hasil}

Hasil skrining fitokimia cabai dilampirkan pada Tabel 1 dan hasil pengamatan histologi lambung tikus disajikan pada Tabel 2. Cabai mengandung senyawa khas Capsaicin yang memberi sensasi pedas ketika dikonsumsi. Tingkat kepedasan cabai bergantung pada kadar Capsaicin yang terkandung di dalamnya. Cabai juga mengandung senyawa flavonoid, alkaloid, fenol, saponin, terpenoid, dan tanin. Pada preparat histologi tersebut terlihat adanya

Tabel 1. Skrining Fitokimia Ekstrak Cabai

\begin{tabular}{lll}
\hline \multicolumn{1}{c}{ Fitokimia } & \multicolumn{1}{c}{ Metode Uji } & Hasil \\
\hline Capsaicin & HPLC & Cabai Hijau $=1,81 \mathrm{mg} / \mathrm{g}$ \\
& & Cabai Merah $=3,54 \mathrm{mg} / \mathrm{g}$ \\
& & Cabai Rawit $=6,37 \mathrm{mg} / \mathrm{g}$ \\
Flavonoid Total & Cabai Hijau $=0,36 \%(\mathrm{~b} / \mathrm{b})$ \\
& & Cabai Merah $=0,58 \%(\mathrm{~b} / \mathrm{b})$
\end{tabular}


Tabel 2. Histologi lambung tikus pada masing-masing kelompok

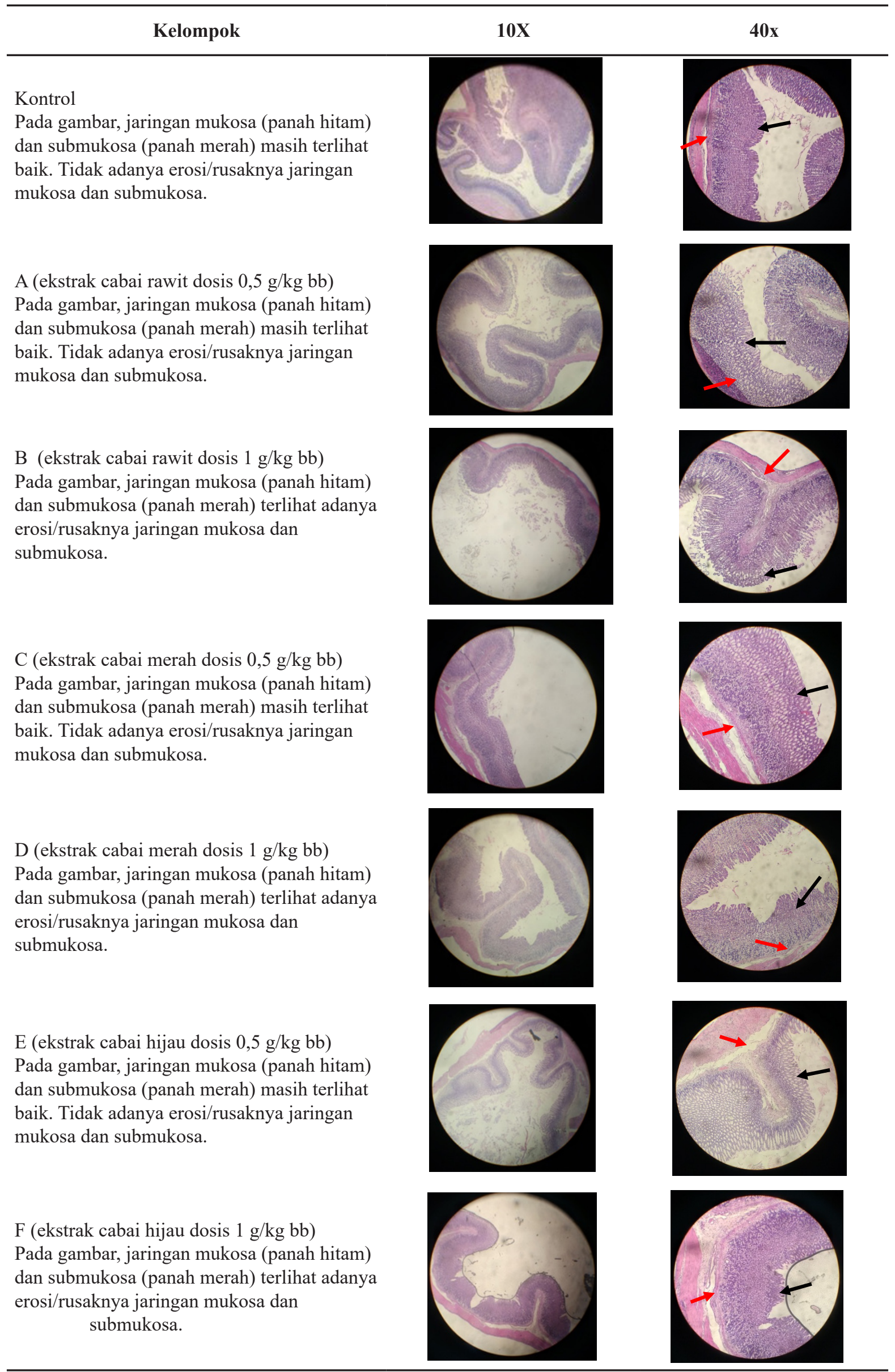


perbedaan kondisi jaringan mukosa dan submukosa lambung pada masing-masing kelompok. Pada lambung normal, jaringan mukosa dan submukosa cukup baik karena tidak terlihat adanya kerusakan (ulkus) dari jaringan mukosa dan submukosa. Pada enam kelompok perlakuan, banyaknya ulkus terlihat pada kelompok yang diberi perlakuan ekstrak cabai rawit dosis $1 \mathrm{gr}$, dan juga pada kelompok yang diberikan ekstrak cabai merah dan cabai hijau dosis tinggi. Perlakuan dengan ekstrak cabai dosis rendah $0,5 \mathrm{gr}$ menunjukkan lapisan mukosa dan submukosa lambung terlihat cukup baik atau normal, tidak ditemukan ulkus atau kerusakan. Secara histologis, ulkus merupakan hilangnya sel epitel yang mencapai atau menembus muskularis mukosa, dengan diameter kedalaman $>5 \mathrm{~mm}$. Ulkus dibedakan dengan erosi, dimana erosi berukuran lebih kecil $(<5$ $\mathrm{mm}$ ) dan lebih superfisial. Mukosa superfisial hanya memiliki pembuluh kapiler, sehingga erosi hanya dapat menyebabkan perdarahan ringan, tidak sampai menyebabkan perdarahan yang signifikan, adanya jaringan parut, atau perforasi seperti ulkus. ${ }^{7}$

\section{Pembahasan}

Lambung memiliki dua mekanisme yang bekerja dan mempengaruhi kondisi lambung, yaitu faktor pertahanan (defense) lambung dan faktor perusak (aggressive) lambung. Kedua faktor ini, pada lambung sehat bekerja seimbang, sehingga lambung tidak mengalami kerusakan/luka. Faktor perusak lambung meliputi: (1) faktor perusak endogen/berasal dari dalam lambung sendiri antara lain $\mathrm{HCl}$, pepsin, dan garam empedu, (2) faktor perusak eksogen, misalnya obatobatan, kafein, alkohol, bakteri, makanan. ${ }^{2}$ Faktor/sistem pertahanan pada lambung meliputi lapisan mukosa lambung yang dibentuk oleh mukus dan $\mathrm{HCO}_{3}{ }^{-}$. Salah satu makanan yang dapat menyebabkan kerusakan lambung adalah makanan yang mengandung cabai. Cabai mengandung suatu senyawa khas yang disebut capsaicin yang memberikan sensasi panas seperti terbakar apabila dikonsumsi. Capsaicin terdapat di bagian plasenta buah cabai yang dekat biji. ${ }^{4}$
Beberapa penelitian menyebutkan bahwa cabai yang dikonsumsi dengan dosis yang tepat dapat membantu mekanisme proteksi lambung (gastroproteksi). Banyaknya varietas cabai yang ada juga menunjukkan perbedaan kandungan capsaicin di dalamnya. Tingkat kepedasan cabai menjadi berbedabeda tergantung pada kadar capsaicin nya. Oleh karena itu, penelitian ini bertujuan untuk menentukan pengaruh ekstrak tiga varietas cabai yang sering dikonsumsi masyarakat dan dosis yang tepat terhadap proteksi lambung.

Hasil pengukuran kadar capsaicin yang terkandung pada cabai dalam penelitian ini menunjukkan kadar yang berbedabeda. Cabai rawit memiliki kadar capsaicin tertinggi yaitu $6,37 \mathrm{mg} / \mathrm{g}$ dibandingkan dua cabai lainnya yaitu cabai merah $3,54 \mathrm{mg} / \mathrm{g}$ dan cabai hijau 1,81 mg/g. Ekstrak cabai yang diberikan dengan dosis rendah tidak menyebabkan kerusakan pada jaringan mukosa dan submukosa lambung, sedangkan ekstrak tiga varietas cabai dengan dosis tinggi menyebabkan kerusakan pada jaringan mukosa dan submukosa lambung. Capsaicin yang terkandung dalam cabai meskipun menimbulkan sensasi panas atau terbakar dan bahkan nyeri, pada dosis tertentu memiliki peran dalam perlindungan lambung. Capsaicin merangsang serat saraf capsaicin-sensitive afferent sensory untuk mengeluarkan CGRP (Calcitonin Gene Related Peptide) yang akan meningkatkan produksi NO (Nitric Oxide). Produksi NO akan meningkatkan aliran darah pada tepi ulkus. Aliran darah di dalam lapisan sub mukosa merupakan faktor dari pertahanan/perbaikan sistem sub epitel. ${ }^{8}$ Mukus yang disekresikan oleh sel leher kelenjar lambung dan sel mukosa permukaan, terdiri atas glikoprotein yang disebut musin dan membentuk suatu gel fleksibel yang melapisi mukosa. Sel mukosa permukaan juga menyekresikan $\mathrm{HCO}_{3}{ }^{-}$. Sebagian besar $\mathrm{HCO}_{3}{ }^{-}$terperangkap dalam gel mukus sehingga terbentuk suatu gradien $\mathrm{pH}$ yang memiliki rentang $\mathrm{pH} 1,0-2,0$ di sisi luminal sampai 6,0-7,0 di permukaan sel epitel. $\mathrm{HCl}$ yang disekresikan oleh sel parietal di kelenjar lambung melintasi sawar ini dalam kanal berbentuk jari, dengan menyisakan lapisan 
gel lain yang utuh. ${ }^{1}$

Faktor pertahanan mukosa lambung juga melibatkan banyak faktor dan enzimenzim. Salah satu pengaturan enzim yang berperan dalam pertahanan mukosa lambung adalah enzim cyclooxygenase (COX) yang memproduksi prostaglandin. Substrat COX adalah prostaglandin $\mathrm{E}_{2} \quad\left(\mathrm{PGE}_{2}\right) . \mathrm{PGE}_{2}$ mencegah kerusakan struktur mukosa lambung dengan meningkatkan sekresi mukus dan memproduksi anion bikarbonat $\left(\mathrm{HCO}_{3}{ }^{-}\right)$yang menetralkan asam lambung dan meningkatkan aliran darah lambung. ${ }^{9}$ Capsaicin juga memiliki aktivitas antibakteri dan menghambat bakteri Helicobacter pylori yang merupakan bakteri perusak jaringan lambung dan menyebabkan ulkus/luka pada lambung. ${ }^{10}$ Hal ini menjadi faktor yang turut berperan sebagai aktivitas proteksi lambung. Dosis tinggi capsaicin yang dikonsumsi dapat menyebabkan nekrosis pada sel dan bahkan memicu sel menjadi kanker. ${ }^{11}$

Berdasarkan hasil skrining fitokimia, cabai juga mengandung senyawa flavonoid, alkaloid, fenol, saponin, terpenoid, dan tanin. Senyawa-senyawa tersebut memiliki manfaat ketika dikonsumsi. Gurnani et al menunjukkan bahwa senyawa Alkaloid memiliki aktivitas antibiotik dan kemampuan mengurangi kadar kolesterol ketika dikonsumsi secara teratur pada dosis rendah. ${ }^{12}$ Jaya et al menunjukkan bahwa makanan yang mengandung banyak fenol dapat mencegah beberapa penyakit seperti kanker, kardiovaskular, inflamasi, neurodegeneratif, dan diabetes. ${ }^{13}$ Saponin merupakan metabolit sekunder yang diproduksi banyak tumbuhan, salah satunya adalah cabai. Saponin memiliki peran sebagai peningkat respon imun, antikanker, anti inflamasi, anti mikroba, dan anti protozoa. ${ }^{14}$

Perbedaan kadar capsaicin yang terkandung di dalam cabai menunjukkan perbedaan tingkat kepedasan cabai. Meskipun cabai memiliki sensai pedas, panas, bahkan nyeri saat dikonsumsi, namun cabai masih tetap menjadi bumbu yang paling banyak dikonsumsi. Cabai dapat memberi manfaat dan memiliki efek perlindungan terhadap lambung (gastroproteksi) ketika dikonsumsi pada dosis yang tepat. Berdasarkan penelitian ini, konsumsi cabai merah, cabai hijau, maupun cabai rawit yang diberikan dengan dosis rendah menunjukkan tidak menyebabkan ulkus pada jaringan mukosa dan submukosa lambung. Sebaliknya, konsumsi cabai pada dosis tinggi menyebabkan kerusakan pada jaringan mukosa dan submukosa lambung.

\section{Simpulan}

Ekstrak cabai dari tiga varietas pada dosis rendah tidak menimbulkan kerusakan pada jaringan mukosa dan submukosa lambung yang berperan sebagai proteksi lambung (gastroproteksi).

\section{Daftar Pustaka}

1. Silverthorn DE. Human physiology (6th ed). USA: Pearson Education Inc; 2013

2. Sherwood L. Human physiology from cell to systems (9th ed). USA: nBrooks/ Cole; 2016

3. Indarti D. Outlook Komoditas Pertanian Sub Sektor Hortikultura Cabai. Pusat Data dan Sistem Informasi Pertanian. Kementrian Pertanian. 2016

4. Fattori V, Hohmann MS, Rossaneis AC, Pinho-Ribeiro FA, Verri WA. Capsaicin: Current understanding of its mechanisms and therapy of pain and other pre-clinical and clinical uses. Molecules. 2016 Jul;21(7):844.

5. Mozsik G. Capsaicin as new orally applicable gastroprotective and therapeutic drug alone or in combination with nonsteroidal anti-inflammatory drugs in healthy human subjects and in patients. Prog Drug Res. 2014;68:209-58.

6. Sandor B, Papp J, Mozsik G, Szolcsanyi J, Keszthelyi Z, Juricskay I, et al. Orally given gastroprotective capsaicin does not modify aspirin-induced platelet aggregation in healthy male volunteers (human phase I examination). Acta Physiologica Hungarica. 2014 Dec 1;101(4):429-37.

7. Kumar V, Abbas AK. Robbins basic pathology 9th ed. USA: Elsevier Inc; 2013

8. McCarty MF, DiNicolantonio JJ, O'Keefe 
JH. Capsaicin may have important potential for promoting vascular and metabolic health. Open Heart. 2015;2:e00262.

9. Kwiecien S, Konturek PC, Sliwowski Z, Mitis-Musiol M, Pawlik MW, Brzozowski B, et al. Interaction between selective cyclooxygenase inhibitors and capsaicin-sensitive afferent sensory nerve in pathogenesis of stress-induced gastric lesions. J physiol pharmacol. 2012;63;2:143-151.

10. Mhaskar RS, Ricardo I, Azliyati A, Laxminarayan R,AmolB, Santosh W, et al. Assessment of risk factors of helicobacter pylori infection and peptic ulcer disease. J. Glob. Infect. Dis. 2013;5:60-67.

11. Fattori V, Hohmann MSN, Rossaneis AC, Pinho-Ribeiroand FA. Verri WA. Capsaicin: Current Understanding of Its Mechanismsand Therapy of Pain and
Other Pre-Clinical and Clinical Uses. Molecules. 2016;21(7):844.

12. Gurnani N, Gupta M, Mehta D, Mehta BK. Chemical composition, total phenolic and flavonoid contents, and in vitro antimicrobial and antioxidant activities of crude extracts from red chilli seeds (Capsicum frutescens L.). Journal of Taibah University for Science. 2016;10(4):462-470

13. Chalise JP, Acharya K, Gurung N, Bhusal RP, Gurung R, Skalko-Basnet N, et al. Antioxidant activity and polyphenol content in edible wild fruits from Nepal. International Journal of Food Sciences and Nutrition. 2010 Jun 1;61(4):425-32.

14. Hussain M, Debnath B, Qasim M, Bamisile BS, Islam W, Hameed MS, et al. Role of Saponins in Plant Defense Against Specialist Herbivores: a review. Molecules. 2019;24(11):2067. 